\title{
Additions to the bryophyte floras of Angola and São Tomé \& Príncipe
}

\author{
Frank Müller, Thea Lauten schläger \& James R. Shevock
}

Additions to the bryophyte floras of Angola and São Tomé \& Príncipe. - Acta Mus. Siles. Sci. Natur., 68: 143-150, 2019.

\begin{abstract}
Five liverwort species (Cheilolejeunea krakakammae, Cololejeunea latilobula, Cylindrocolea abyssinica, Telaranea nematodes, Thysananthus humilis) and five moss species (Calyptothecium planifrons, Calymperes tenerum, Fissidens usambaricus, Leptotrichella nitidula, Trichostomum lorifolium) are reported as new for the bryophyte flora of Angola. Fossombronia indica is reported as new for the country of São Tomé and Príncipe, Gulf of Guinea, West Africa. An additional two hepatic species (Lejeunea acuta, Solenostoma dusenii) are reported as new for Príncipe.
\end{abstract}

Key words: biodiversity, bryophytes, distribution, Gulf of Guinea, inventory, tropical forests, liverworts, mosses, new records, Palaeotropis, Africa

\section{Introduction}

Angola is one of the most poorly known countries in Africa for its bryophyte flora. Müller (2015) reported 94 new records of liverwort and moss taxa for Angola. The collections on which these results are based were made mainly by the first author during a 10-day collecting trip in 2013, supplemented by a few additional specimens collected by the second author with Matthias Nuß. These collections were made mainly in the province of Uíge, which is situated in the far north part of Angola about $200 \mathrm{~km}$ northeast of the capital Luanda. An additional new species record for Angola was reported by Müller et al. (2018). During 2015, 2016, 2017, and 2018 the second author made four trips to Angola and has collected additional bryophyte material. Among this material there are several species new for Angola.

In the last years we have published a series of papers on the bryophyte flora of São Tomé and Príncipe mainly basing on the results of the determination of the extensive material collected by the third author during three collecting expeditions in the years 2010, 2012, and 2013 (Enroth \& Shevock 2011, Müller et al. 2011, Müller \& Shevock 2018, Pócs et al. 2015, Shevock et al. 2013, Sollman et al. 2016). A subsequent expedition in 2016 revealed additional new records for the country or for individual islands.

In this paper we would like to present these new records for Angola and São Tomé \& Príncipe.

\section{Results}

The following inventory of taxa lists new distributional records for the countries of Angola and São Tomé \& Príncipe, and for individual islands, that have not been previously published. The collections in Angola were made by the second author during 2015-18. If not otherwise stated this material was determined by the first author. The collections in São Tomé and Príncipe were made by the third author on an expedition during November 2016. If not otherwise stated, this material was determined by the first author. Voucher specimens are conserved in the herbaria indicated behind the collection numbers (São Tomé and Príncipe) or behind the collector names (Angola specimens). Ten new country records for Angola, one new country record for São Tomé and Príncipe and two new records for Príncipe are presented. 


\section{ANGOLA}

\section{Calyptothecium planifrons (Ren. \& Card.) Argent}

Angola: Province Uíge, Quimbele $30 \mathrm{~km} \mathrm{~S}$, swampy forest area, epiphytic, $1056 \mathrm{~m}, 6^{\circ} 46^{\prime} 54.5^{\prime \prime} \mathrm{S}, 16^{\circ} 12^{\prime} 30.7^{\prime \prime} \mathrm{E}$, $23 \mathrm{Jul}$ 2015, T. Lautenschläger (DR 44288).

New for Angola. The species was described from Madagascar and for a long time it was regarded as an African endemic, but later the species was also recorded from the Neotropics (Reese 1985). In Africa the species is relatively rare, and reported from Central African Republic, Chad, Kenya, Madagascar, Tanzania, Democratic Republic of the Congo, and Zambia (O'Shea 2006). At the new site in Angola the species was found growing as epiphyte in a swampy forest embedded in forest savannah (Fig. 1). At this site the species is accompanied by Leucomium strumosum (Hornsch.) Mitt., Pelekium varians (Welw. \& Duby) Touw and Rhacopilopsis trinitensis (Müll.Hal.) Dixon. On the forest ground there is growing Sphagnum planifolium Müll.Hal., a species just recently reported as new for Angola from Mucaba forest about c. $130 \mathrm{~km}$ to the WSW (Müller 2014).

\section{Calymperes tenerum Müll.Hal.}

Angola: Province Uíge, Uíge $54 \mathrm{~km}$ WNW, secondary forest (banana plantation), on rocks, $445 \mathrm{~m}, 7^{\circ} 31^{\prime} 28.0^{\prime \prime} \mathrm{S}$, 14³4'04.1’'E, 14 Oct 2016, T. Lautenschläger (DR 44428).

New for Angola. This pantropical species is common and abundant in the Indo-Malaysian region and Oceania but rarer in the Americas and Africa (Reese 1987). It is quite widespread on the islands of the western Indian Ocean. In mainland Africa and from the islands in the Gulf of Guinea it is known from Benin, Bioko, Ghana, Ivory Coast, Kenya, Nigeria, South Africa, Tanzania, and D.R. Congo (O'Shea 2006).

\section{Cheilolejeunea krakakammae (Lindenb.) R.M.Schust.}

Angola: Province Uíge, Uíge $25 \mathrm{~km} \mathrm{NE}$, Pambu, secondary forest (coffee plantation), epiphytic, $1244 \mathrm{~m}$, 7²5'59.1”S, 15¹0’23.1”E, 19 Jul 2015, T. Lautenschläger (DR 44301 \& 44302).

New for Angola. A palaeotropical species, known from New Zealand, Australia, Asia and Africa. In Africa the species is mainly distributed from the eastern and southern part of mainland Africa and from the East African islands. Müller \& Pócs (2007) reported it first for West Africa from Bioko.

\section{Cololejeunea latilobula (Herzog) Tixier}

Angola: Province Uíge, Uíge $54 \mathrm{~km}$ WNW, Gruta de Zenzu, $562 \mathrm{~m}$, wet forest, epiphytic, $7^{\circ} 31^{\prime} 09.5^{\prime \prime} \mathrm{S}$, 14³3'53.7’'E, 23 Nov 2015, T. Lautenschläger (DR 44349)

New for Angola. A pantropical species, previously known to be restricted to Asia and Africa, but in recent years also reported from the Neotropics (Pócs et al. 2014). In Africa the species was known for a long time as $C$. himalayensis (Pandé \& Misra) R.M.Schust. and under this name it is treated in Wigginton (2004), a species synonymized under $C$. latilobula by Tixier (1985). In Africa the species is previously known from Burundi, Comores, D.R. Congo, Ethiopia, Malawi, Nigeria, Réunion, Rio Muni, Rwanda, Seychelles, Tanzania, Uganda, and Zambia (Wigginton 2018).

\section{Cylindrocolea abyssinica (Gola) Váňa}

Angola: Province Uíge, Quimbele $10 \mathrm{~km} \mathrm{~S}$, Kibokolo forest, forest savannah, epiphytic, $834 \mathrm{~m}, 6^{\circ} 36^{\prime} 47.5^{\prime \prime} \mathrm{S}$, 16²'14.9’E, 21 Jul 2015, T. Lautenschläger (DR 44315).

New for Angola. Endemic to Africa where it is already known from Central African Republic, Cameroun, D.R. Congo, Ethiopia, Ghana, Ivory Coast, Lesotho, Madagascar, Mozambique, Nigeria, Rwanda, South Africa, Sierra Leone, Swaziland, Tanzania, Uganda, and Zimbabwe (Wigginton 2018). As reported by Wigginton (2004) this species is not always 
confined to sites of high humidity, and therefore, penetrating from the rainforest to the wet savannah zone. The new site in Angola is also situated in forest savannah (Fig. 2), where it is growing as an epiphyte.

\section{Fissidens usambaricus Broth.}

Angola: Province Uíge, Uíge $21 \mathrm{~km} \mathrm{SW}$, Serra Pingano, rainforest, earthy slopes, $666 \mathrm{~m}, 7^{\circ} 43^{\prime} 43.7^{\prime \prime} \mathrm{S}$, 1454'05.8”E, 20 Feb 2017, T. Lautenschläger (DR 54789); Province Uíge, Maquela do Zombo 75 km WNW, forest remnant, 796 m, 558'28.7'S, 1453'08.5'E, 24 Feb 2017, T. Lautenschläger (DR 54791)

New for Angola. A widespread African endemic, known from Macaronesia (Cape Verde Islands), west tropical Africa (Ivory Coast, Nigeria), west central tropical Africa (Cameroon, Central African Republic, D. R. Congo, Gabon, Rwanda, São Tomé), northeast tropical Africa (Ethiopia), east tropical Africa (Kenya, Tanzania, Uganda), south tropical Africa (Malawi), and southern Africa (South Africa, Swaziland) (Bruggeman-Nannenga 2017).

\section{Leptotrichella nitidula (Mitt.) Ochyra}

Angola: Province Uíge, Uíge $170 \mathrm{~km} \mathrm{~N}$, Maquela, on open soil banks together with Fissidens intromarginatus, 855 m, 604'24.3”S, 15¹2'56.9”'E, 17 Feb 2018, T. Lautenschläger (DR 54794).

New for Angola. In Africa the genus is still in need of a critical revision. In O'Shea (2006) there are listed about 10 species for sub-Saharan Africa and many of them are only known from a single locality or country. More widely distributed in Africa are L. minuta (Hampe) Ochyra, a species restricted to southern and eastern Africa including the East African islands, and L. nitidula, a West African species previously known from Central African Republic, Gabon, Ghana, Ivory Coast, Nigeria, Togo, and D.R. Congo (O'Shea 2006). From the same distribution area as L. nitidula there is also reported L. subnitidula (Thér. \& P.de la Varde) Ochyra, but this species could be separated by slightly falcate, more longer tapering leaves and capsules constricted below the mouth (Potier de la Varde 1936).

\section{Telaranea nematodes (Austin) M.Howe}

Angola: Province Uíge, Mucaba 6 km NE, forest remnant, epiphytic, 1209 m, 7¹3’00.7’'S, 1505’44.8”'E, $26 \mathrm{Jul}$ 2015, T. Lautenschläger (DR 44272).

New for Angola. The species complex of T. nematodes was revised by Engel \& Smith Merrill (2004). In the past there was a confusion between this species and T. bicruris (Steph.) M.Howe, T. chaetophylla (Spruce) Schiffn., T. europaea Engel \& Merr., T. longifolia (M.Howe) Engel \& Merr., T. redacta (Steph.) Engel \& Merr., and T. sejuncta (Ångstr.) S.Arnell. Therefore, the distribution given in the literature is in need of a critical re-evaluation. On the basis of recently examined specimens, Engel \& Smith Merrill (2004) states tropical America and Africa (Ghana, Sierra Leone, Uganda, São Tomé) as the range of the species. Wigginton (2018) lists records of the species from many African countries (Bioko, Burundi, Comores, D.R. Congo, Ethiopia, Gabon, Ghana, Kenya, Madagascar, Malawi, Réunion, Rio Muni, Rwanda, South Africa, São Tomé, Sierra Leone, Tanzania, Togo, Uganda, Zambia, Zimbabwe). In Angola the species was found in a swampy forest developed on nutrient pure sandy soil near of Mucaba (Fig. 3), a remarkable area with many floristically important vascular plants. From a bryological point of view high quantities of Sphagnum planifolium are remarkable.

Thysananthus humilis (Gottsche) Sukkharak \& Gradst.

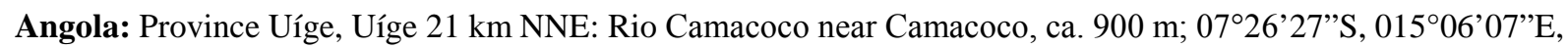
16 Oct. 2013, F. Müller (DR 41546); Province Cuanza Norte, N'dalatando 4 km SW: Botanical Garden, ca. 735 m; 9²0'02”'S, 1453'56”'E, 17 Oct. 2013, F. Müller (DR 41517).

In the past, e. g. in the Flora of E. W. Jones's (Wigginton 2004), which was used for the determination of the Mastigolejeunea material cited in Müller (2015), M. humilus (Gottsche) Schiffn. is treated as a synonym of $M$. auriculata (Wilson) Steph. In a recent revision 
(Sukkharak \& Gradstein 2014), both are treated as separate species and later they were transferred in the genus Thysananthus (Sukkharak \& Gradstein 2017). The material cited in Müller (2015) was partly revised in 2016 by P. Sukkharak. The above mentioned specimens, previously treated under $M$. auriculata, were revised and belonging to $T$. humilis, a palaeotropic species. In Africa this species is probably the most widely distributed species of "Mastigolejeunea", which can herewith be reported for the first time for Angola.

Trichostomum lorifolium Broth. \& Paris

Angola: Province Malanje, Uíge 117 km E, river Cauale, epiphytic, 835 m, 7³7'02.3”S, 1605'09.7’E, Oct 2016, T. Lautenschläger (DR 44439), det. Ph. Sollman. Province Uíge, Uige $153 \mathrm{~km} \mathrm{NE,} \mathrm{Milunga,} \mathrm{epiphytic,}$ 656'20.7'S, 16 16'08.1'E, 24 February 2018, T. Lautenschläger (DR 54793); Province Uíge, Uíge 54 km WNW, Municipality Ambuila, on limestone rocks, 628 m, 7³1'04.0”S, 14³4'07.4’E, 13 Oct 2015, T. Lautenschläger (DR 54792).

New for Angola. The genus Trichostomum is still in need of a critical revision in Africa. The species was described by Brotherus \& Paris in Paris (1904) from the former Guinee francaise, now Guinea. The species is known from Central African Republic, Guinea, Malawi, Nigeria, Tanzania, D.R. Congo (O‘Shea 2006). Trichostomum mahaliesmontanum Rehm., an invalidly published name, collected by Rehman in Transvaal, is treated as a synonym of T. lorifolium in Khmil et al. (2013). Trichostomum lorifolium is characterized by very fragile leaves. In Angola the species was found growing on rocks and as an epiphyte on tree bark.

\section{SÃO TOMÉ AND PRÍNCIPE}

\section{Fossombronia indica Steph.}

Príncipe: Along dirt road along the east coast between Nova Estrela and Tirreiro Velho, disturbed secondary hardwood forest, vertical soil bank of road, $200 \mathrm{~m}$ alt., 01 '36'47.0'N, 07²5'29.3”'E, 17 Nov 2016, Shevock 49870 (CAS, DR, EGR)

New for São Tomé and Príncipe. In Müller et al. (2011) we reported the presence of the genus Fossombronia for Príncipe. As only material without sporophytes was available, at this time a determination to species level was impossible. During the 2016 expedition it was possible to collect material with ripe sporophytes. The determination using the sporophyte characteristics results in a belonging of the material to $F$. indica. Fossombronia indica was described from Mangalore, in the state of Karnataka, southwest India, by Stephani (1917). Later the West African F. occidento-africana S.W.Arnell was regarded as synonymous with it (Scott \& Pike 1988).

Our material matches well the descriptions and illustrations in Wigginton (2004) and Cargill (2000). The capsule wall thickenings are mostly nodular throughout, including most of the basal portion (Fig. 4D). The distal spore face is composed of a web of lamellae which form a network of small, mostly incomplete reticulae (Fig. 4A). The proximal spore face has a distinct triradiate mark, with each segment densely covered with short low lamellae (Fig. 4B). The elaters are elongate and composed of 2-3 lax spirals (Fig. 4C).

In Africa the species was hitherto known from Ascension, Ghana, Nigeria, Sierra Leone, and Togo (Wigginton 2018).

\section{Lejeunea acuta Mitt.}

Príncipe: Obô Natural Park de Príncipe: cross-country route across the summit of the Mesa, mixed tropical hardwood cloud forest, on hardwood liana, mixed with Lejeunea flava, $500 \mathrm{~m}$ alt., $01^{\circ} 34^{\prime} 53.4^{\prime \prime} \mathrm{N}, 07^{\circ} 20^{\prime} 52.4^{\prime} \mathrm{E}$, 22 Nov 2016, Shevock 50003 (CAS, DR, EGR), det. T. Pócs.

The species was already known from São Tomé, but in Wigginton (2018) it is not mentioned for Príncipe. In Sérgio \& Garcia (2011) there is an indication of its occurrence on Príncipe, but without citing a relevant specimen. On São Tomé the species is widely distributed at higher elevations in montane rainforests. In the collections of the third author it is presented 
by several specimens from São Tomé, but the above mentioned specimen is the only one from Príncipe.

Lejeunea acuta is an African endemic known from Annobon, Bioko, Burundi, Cameroun, Comores, D.R. Congo, Kenya, Rio Muni, Rwanda, São Tomé, Tanzania, and Uganda (Wigginton 2018).

\section{Solenostoma dusenii (Steph.) Váňa, Hentschel \& Heinrichs}

Príncipe: Obô Natural Park de Príncipe: Watershed of the Rio Banzu, along the Rio Banzu less than $2 \mathrm{~km}$ from ruins of roça S. Carlos do Fundão, mixed hardwood forest, on volcanic rock wall in river, $190 \mathrm{~m}$ alt., $01^{\circ} 36^{\prime} 03.0^{\prime \prime} \mathrm{N}$, 07²3'13.5'E, 15 Nov 2016, Shevock 49804 (CAS, DR, EGR); Obô Natural Park de Príncipe: along the Rico Porco about $300 \mathrm{~m}$ above confluence with ocean, mixed hardwood forest, on vertical soil bank, $50 \mathrm{~m}$ alt., 01³3'06.0'”, 07²2'42.0”'E, 18 Nov 2016, Shevock 49881 (CAS, DR, EGR).

New for Príncipe. The species is a West African endemic and hitherto known from Bioko, Cameroun, and São Tomé (Wigginton 2018). The species was originally described from material collected by Dusén from rocks in rivers on the lower slopes of Mt. Cameroon (Wigginton 2004). From São Tomé the species was hitherto known based on a single Moller's gathering (Váňa 1974, Sérgio \& Garcia 2011), but in the recent collection of the third author there are several specimens from São Tomé and the above mentioned specimens from Príncipe, which represent a new record for this island.

\section{Discussion}

The results indicate that additional bryophyte records are very likely to be documented with ongoing field work and exploration. This observation is especially valid for Angola, a bryologically very badly documented country (Müller 2014). In São Tomé and Príncipe the systematic field inventory of the third author has revealed a relatively good status of the knowledge of the hepatic flora for this country. More systematic field inventory sampling in remote areas of Príncipe and at the higher altitudes of São Tomé would be a profitable enterprise and further define the distribution of Gulf of Guinea bryophytes.

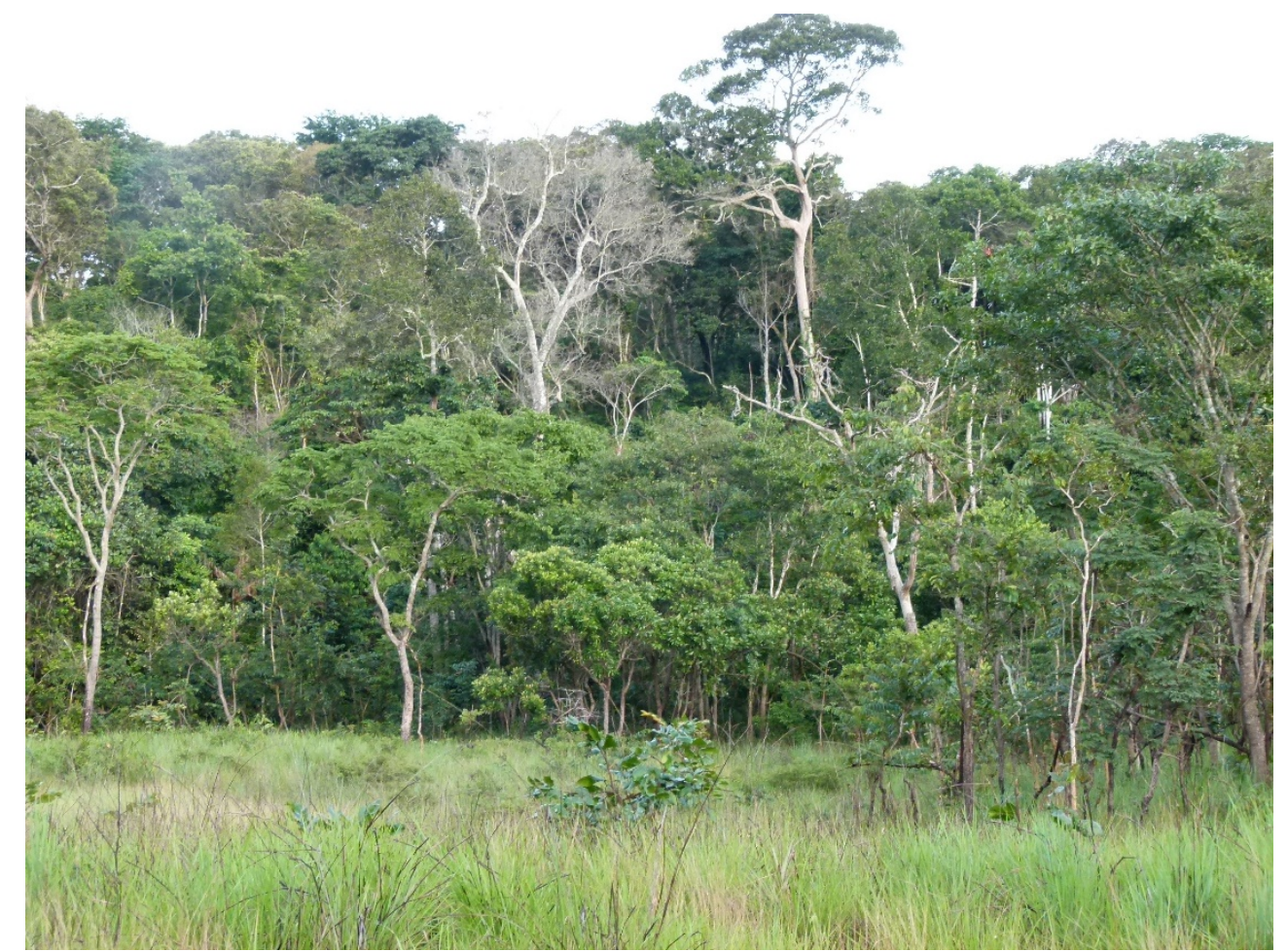

Fig 1: Swampy forest embedded in forest savannah near Quimbele. At this site Calyptothecium planifrons was found as epiphyte. 


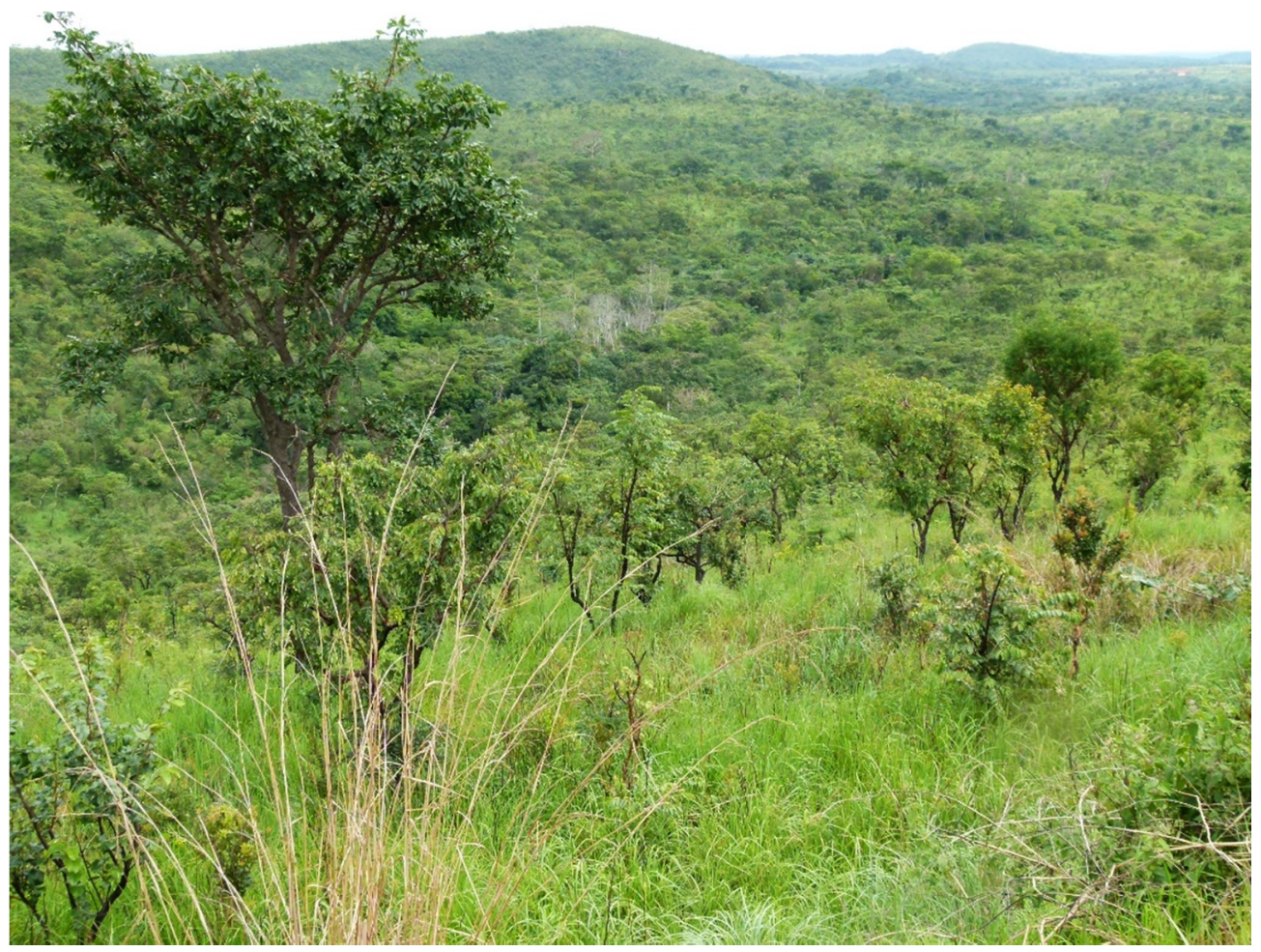

Fig 2: Forest savannah near Kibokolo south of Quimbele, the record site of Cylindrocolea abyssinica which was found here growing as epiphyte.

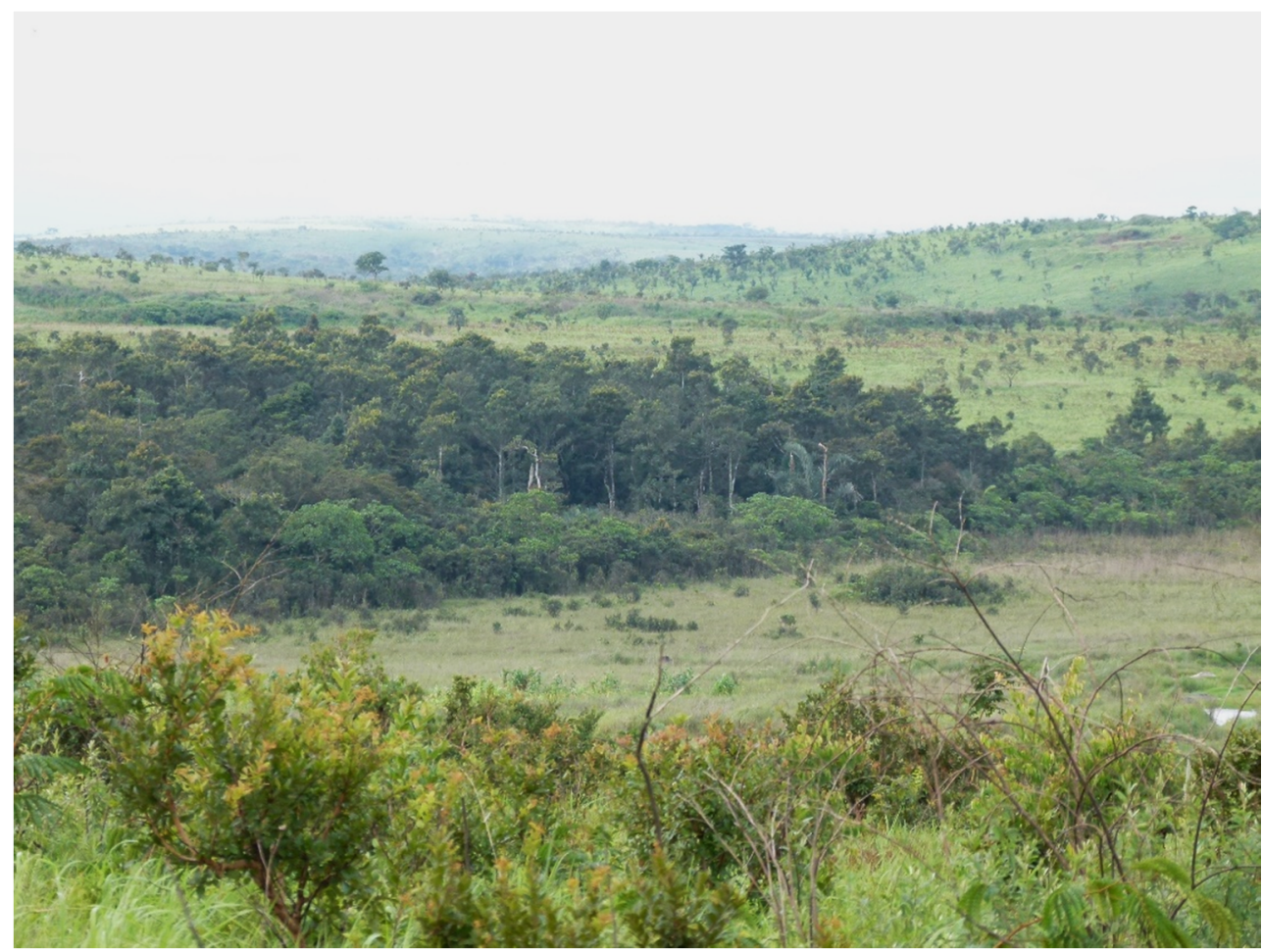

Fig 3: Swampy forest developed on nutrient pure sandy soil and surrounded by cultivated land near of Mucaba, record site of Telaranea nematodes, Sphagnum planifolium and remarkable vascular plants. 

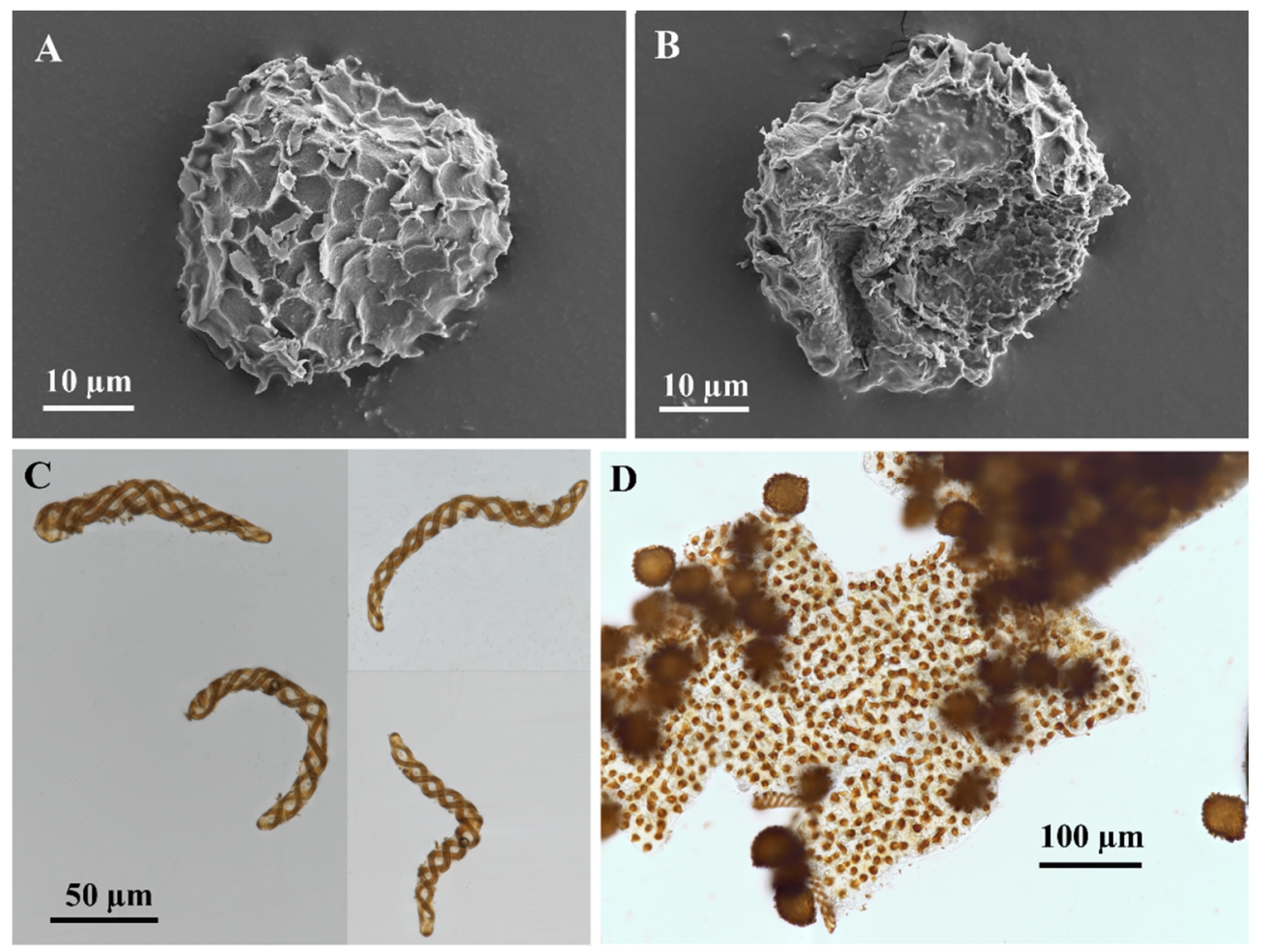

Fig 4: Fossombronia indica. A: Spore in distal view. B: Spore in proximal view. C: Elaters. D: Part of capsule wall. (All from Shevock 49870 (DR)).

Acknowledgment: The fieldwork of Thea Lautenschläger and Frank Müller in Angola was supported by travel funds from the German Academic Exchange Service (DAAD) and the Strategic Partnerships program of the Technische Universität Dresden. These published results were obtained in collaboration with the Instituto Nacional da Biodiversidade e Áreas de Conservação (INBAC) of the Ministério do Ambiente da República de Angola. We thank the administration and the staff of the University of Kimpa Vita in Uíge for financial and logistical support and participating in the fieldwork during the stay in Angola.

Bryological collecting activities of J. Shevock in São Tomé and Príncipe was made possible by Arlindo Carvalho and Faustino de Oliveira of the Ministry of Environment, Republic of São Tomé and Príncipe and the staff at Parque Natural de Obô de São Tomé and Daniel Ramos, Director of Parque Natural de Obô de Príncipe and is greatly appreciated. Funding for travel during four expeditions was provided by the California Academy of Sciences (CAS) Gulf of Guinea Fund and Internal Research Grant. Staff at Bom Bom Resort (Príncipe) and Omali Lodge (São Tomé) made the extended stay enjoyable. Ostelmo Rocha on Príncipe and Estevão Soares on São Tomé served as field guides providing opportunities to explore remote regions which greatly enhanced the collecting experience. A special thanks to Robert Drewes as CAS São Tomé and Príncipe expedition leader for logistical support during these expeditions.

We thank Philip Sollman for the determination of a specimen of Trichostomum lorifolium and Phiangphak Sukkharak for checking Thysananthus specimens.

\section{References}

Bruggeman-Nannenga M.A. (2017): Fissidens Subgenus Aloma (Bryophyta) in Tropical Africa I. The largecelled costate and ecostate species. - Polish Botanical Journal 62(2): 139-168.

Cargill D.C. 2000. A taxonomic revision of Fossombronia and Sewardiella, suborder Fossombroniineae (Marchantiophyta, Metzgeriidae) within the continent of Africa, Southwest Asia and the sub-continent of India. - Dissertation, Department of Plant Biology in the Graduate School of Southern Illinois University at Carbondale, $443 \mathrm{pp}$.

Engel J.J. \& Smith Merrill G.L. (2014): Austral Hepaticae 35: a taxonomic and phylogenetic study of Telaranea (Lepidoziaceae) with a monograph of the genus in temperate Australasia and commentary on extraAustralasian taxa. - Fieldiana n.s. 44: 1-265.

Enroth J. \& Shevock J.R. (2011): Porotrichum saotomense sp. nov. (Neckeraceae) and other additions to the moss flora of São Tomé \& Príncipe, Gulf of Guinea, West Africa. - Tropical Bryology 33: 6-11. 
Khmil T.S., Mamchur Z.I. \& Kondratyuk S.Y. (2013): Antoni Rehman's collection of mosses from South Africa in the herbarium of Ivan Franko National University of Lviv (LW). The Ivan Franko National University of Lviv, Lviv, 134 pp.

Müller F. (2006): Bryophytes of Bioko (Equatorial Guinea). Results of an excursion in 2002. - Tropical Bryology 27: 9-17.

- (2015): About 150 years after Welwitsch - a first more extensive list of new bryophyte records for Angola. Nova Hedwigia 100: 487-505.

Müller F. \& Pócs T. (2007): A contribution to the knowledge of epiphyllous bryophytes of Bioko Island (Equatorial Guinea), including additional remarks on non-epiphyllous species. - Journal of Bryology 29: 8194.

Müller F., Pócs T. \& Shevock J.R. (2011): Additions to the liverwort and hornwort flora of São Tomé and Príncipe. - Tropical Bryology 33: 19-22.

Müller F. \& Shevock J.R. (2018): Marchesinia principensis (Marchantiophyta, Lejeuneaceae), a new liverwort species from Príncipe, West Africa. - Phytotaxa 338(2): 202-208.

Müller F., Sollman P. \& Lautenschläger T. (2018): A new synonym of Weissia jamaicensis (Pottiaceae, Bryophyta), and extension of its range from the Neotropics to the Palaeotropics. - Plant and Fungal Systematics 63(1): $1-5$.

O'Shea B.J. (2006): Checklist of the mosses of sub-Saharan Africa (version 5). - Tropical Bryology Research Reports 6: 1-252.

Paris J.G.E.N. (1904): Muscinées de l'Afrique occidentale française. - Revue Bryologique 31: 83-90.

Pócs T., Bernecker A. \& Tixier P. (2014): Synopsis and key to species of Neotropical Cololejeunea (Lejeuneaceae). - Acta Botanica Hungarica 56: 185-226.

Pócs T., Müller F. \& Shevock J.R. (2015): Additions to the liverwort and hornwort flora of São Tomé and Príncipe II, with Neurolejeunea, a genus new to Africa. - Herzogia 28: 50-69.

Potier de la Varde R. (1936): Mousses du Gabon. - Mémoires de la Société Nationale des Sciences Naturelles et Mathématiques de Cherbourg 20: 1-272.

Reese W.D. (1985): Tropical lowland mosses disjunct between Africa and the Americas, including Calyptothecium planifrons (Ren. \& Par.) Argent, new to the Western Hemisphere. - Acta Amazonica, Suppl., 15(1-2): 115-121.

- (1987): Calymperes (Musci: Calymperaceae): world ranges, implications for patterns of historical dispersal and speciation, and comments on phylogeny. - Brittonia 39: 225-237.

Scott G.A.M. \& Pike D.C. (1988): Revisionary notes on Fossombronia. - The Bryologist 91: 193-201.

Sérgio C. \& Garcia C. (2011): Bryophyte flora of São Tomé e Príncipe Archipelago (West Africa): annotated catalogue. - Cryptogamie Bryologie 32: 145-196.

Shevock J.R., Pursell R.A., Garcia G., Bruggeman-Nannenga M.A. \& Sérgio C. (2013): The genus Fissidens in the Republic of São Tomé and Príncipe, Gulf of Guinea, West Africa. - Journal of Bryology 35: 197-205

Sollman P., Shevock J. \& Garcia C. (2016): Mosses in the family Pottiaceae newly reported for the Republic of São Tomé and Príncipe, West Africa. - Cryptogamie Bryologie 37: 455-461.

Stephani F. (1917): Species Hepaticarum, Vol. 6. George \& Cie, Geneve \& Bale.

Sukkharak P. \& Gradstein S.R. (2014): A taxonomic revision of the genus Mastigolejeunea (Marchantiophyta: Lejeuneaceae). - Nova Hedwigia 99(3): 279-345.

- (2017): Phylogenetic study of Mastigolejeunea (Marchantiophyta: Lejeuneaceae) and an amended circumscription of the genus Thysananthus. - Phytotaxa 326: 91-107.

Tixier P. (1985): Contribution à la Connaissance des Cololejeuneoideae. - Bryophytorum Bibliotheca 27: 1-439.

Váňa J. (1974): Studien über Jungermannioidae. 5. Jungermannia subgen. Plectocolea und subg. Solenostoma: Afrikanische Arten. - Folia Geobotanica et Phytotaxonomica 9: 277-312.

Wigginton M.J. (ed.) (2004): E. W. Jones's Liverwort and Hornwort Flora of West Africa. - Scripta Botanica Belgica 30: 1-443.

- (2018): Checklist and distribution of the liverworts and hornworts of sub-Saharan Africa, including the East African Islands. Ed. 4. - Tropical Bryology Research Reports 9: 1-138.

Authors' addresses: Frank Müller, Institut für Botanik, Technische Universität Dresden, Mommsenstr. 13, 01062 Dresden, Germany. E-mail: frank.mueller@tu-dresden.de

Thea Lautenschläger, Institut für Botanik, Technische Universität Dresden, Mommsenstr. 13, 01062 Dresden, Germany. E-mail: thea.lautenschlaeger@tu-dresden.de

James R. Shevock, Department of Botany, California Academy of Sciences, 55 Music Concourse Drive, Golden Gate Park, San Francisco, California 94118-4503, USA.

E-mail: jshevock@calacademy.org 